Industry and the University Grants Committee) and recreating the circumstances that enabled Mr Watt to prosper. Even though the torrent of advice that the government is now given about the exploitation of biotechnology is largely empty of constructive content (because it supposes that all innovations will be conducted within the framework to which all have grown accustomed), the fact that there is so much of it must surely be a sign that something needs to be decided.

The case of biotechnology is marvellously illustrative of what lies ahead. Popular legend has it that laboratory discoveries in the immediate past could be made the foundation of a brave new industry, one so productive and profitable that, with a little luck, some entrepreneurial government might succeed as James Watt did. Modern biotechnology will indeed change the world in welcome ways, but not necessarily more profoundly than it has done so already. (Where would we be without bread, or cheese, or wine?) Equally, however, it is certain that in the long run the benefits will accrue to those commercial organizations that are so technically and financially strong, or so imaginative and fiscally free, that they can make the best bargains with their present customers and an uncertain future. Inevitably, of course, in the intervening years or decades, many small enterprises will spring into being (and some may even prosper in the long term), but those responsible for founding them will only rarely make their marks by becoming household words, names on some pharmaceutical package or other new commodity. Most will be content to sell out to larger partners, and some will be glad to do so. Those doubting that calculation should consider what happened to the manufacturers of automobiles who set out a century ago on their endeavour. The difference, now, is that the market, both for products and people, is international. The House of Commons committee at least knows that.

So why should not Britain follow in biotechnology where the government of France appears to be going in its attempt to make a new electronics industry (see page 507)? Because the British have been through that, most recently in the 1960s. Many of the projects mounted then in the belief that profligate public investment in new technology must be virtuous are only now being painfully abandoned - the aluminium smelter in the north of Scotland, for example. What has stuck in the British mind is merely that this is a recipe for an inflation rate that is insupportable. If the French avoid that painful trauma, it will be because their civil servants are more businessmen than bureaucrats.

The British government's concern, in the face of the conflicting advice being showered on it, must be to give British industry a sporting chance of survival. How should that be done? Most committees with an opinion on the subject say that British universities are even in penury remarkably productive of good fundamental research, but the research councils' own committee of officials acknowledges that the peer-review system may inhibit applied research in universities (see page 507). That is not, of course, a contradiction but a simple consequence. Who is to change it, and how? Certainly there is no room for change within the present system, although there might be if universities were genuinely autonomous and not as at present constrained by an invidious numerus clausus applied to their total size. The time has probably come when the British system for research support must follow the course being followed by universities in the United States, looking for closer links betwen universities and industry (with all the discomfort that must follow), in which case tax concessions are necessary - not merely matters to be studied. And while the research councils themselves are probably quite able managers of their own research and development, there is very little to be said for allowing them to continue as they are while the work they do might as well be done in the more flexible (and perhaps cheaper) environment of the universities. The House of Commons committee is right to say that change is overdue, but it underestimates the degree to which the necessary change must be radical. A formal channel of communication between the Department of Industry and the University Grants Committee is not a sufficient substitute.

\section{Talk, guns and butter}

\section{President Reagan is more flexible about India than his predecessor, but still has much to learn.}

President Reagan's diplomacy is better than that of his predecessor, Jimmy Carter, at least where relations with India are concerned. By working out an ingenious way round the impasse over the supply of nuclear fuel to India (see p.503), Reagan has extricated US diplomacy from the trap created by Carter, who campaigned against nuclear proliferation, supported the 1978 anti-proliferation act but then had to bend to Indian pressure and send nuclear fuels to a state that has consistently refused to forswear the development of nuclear weapons. The relief that greeted the Tarapur deal last week in Washington indicated that a thaw in US-Indian relations is overdue. But a thaw does not solve the problems of that part of the world nor signal a clear path for future US diplomacy. Indeed, the Tarapur deal may be a little too cynical. After all, why should the United States, with its long record of efforts to prevent proliferation, bow to a nation that was the chief opponent of the Nuclear Non-Proliferation Treaty, and which mightily inflamed the nuclear ambitions of other developing countries with its "peaceful" nuclear test in 1974 ?

Why should Mrs Gandhi, who otherwise seemed to be bearing olive branches to Washington last week, keep the nuclear weapons option open? "We do not have nuclear weapons", she told a gathering at the National Press Club, sounding faintly like those Israeli generals who always deny that Israel has "deliverable" nuclear bombs. Most people, especially the Pakistanis who seem to be bent on a nuclear weapons capability of thier own, assume that India could use a nuclear weapon if it so chose. Is it not, after all, an emblem of India's advanced science and technology? India says the reason for keeping the nuclear weapons option open is Pakistan, and has been highly critical of the new $\$ 3,200$ million dollar arms package the Reagan Administration has put together for India's worst enemy. Ever since the Soviet invasion of Afghanistan in 1980, Washington has tried to treat the Pakistani government as some kind of Western bulwark. Yet the military aid, as usual, seems not to be going to fortify Pakistan defences along the Afghan border as intended. According to Mrs Gandhi, the arms keep massing on the Indian border, and attempts to sign a "no-war pact" seem always to end in failure.

This is one reason why Mrs Gandhi was in Washington last week: to rectify the long-standing impression that India "tilts" to the Soviet Union, and thus is forcing Washington to "tilt" to Pakistan. Asked point-blank which way India is tilting these days, Mrs Gandhi told a reporter "We stand upright" - and her American audience applauded. She also hinted that it might be possible for the Soviets to leave Afghanistan under some kind of negotiated agreement - a development that would also remove Washington's need to support Pakistan. But such global machinations could hardly be carried out in a single state visit. "Our main purpose is to put across the Indian point of view" she explained. She appeared to imply that she would be returning to Washington.

Mrs Gandhi also had a more specific purpose: to persuade the President that India needs substantial low-cost loans from other governments and international lending institutions if it is to become the kind of free-enterprise state the President would admire. On this point, however, she did not succeed. Although she stressed India's progressive Western-oriented view of development - hence India's interest in bilateral science cooperation with the United States - she failed to turn that impression into money. Apparently the President insisted that there could be no increase of the US contribution to the International Development Association (which mainly lends to India) and urged her to borrow in the commercial markets. So President Reagan has extended a handshake even while denying India a scrap of extra money to aid Indian development, science and technology. It is politic for the President to be that tough, but is it wise? 